\title{
L’inuktitut et le corps-vocal dans le cinéma inuk : la décolonisation par le poème cinématographique
}

\section{Karine Bertrand \\ Queen's University}

Les Peuples autochtones du Canada furent pendant de nombreuses décennies les spectateurs de leur représentation, leur épopée étant écrite, narrée et mise en images par des médiateurs externes, qui ne surent traduire avec justesse les subtilités d'une culture fondée sur l'oralité. Or, depuis les trente dernières années, les communautés autochtones ont développée de nombreuses stratégies de décolonisation, entre autres en utilisant le langage du colonisateur afin d'explorer les possibilités de renégociations de la langue, en intégrant parfois des mots ou des expressions issues de leur langue traditionnelle à leurs propres écrits en langue française ou anglaise (Henzi 2010). Ce faisant, l'autochtonisation de ces langues officielles, ainsi que la plus grande visibilité donnée aux langues autochtones, permet aux écrivains, artistes et cinéastes autochtones de leur culture orale, à travers un processus de remédiation. Suivant cette ligne de pensée, cet article propose une exploration du corpsvocal dans la poésie inuit, dans le long-métrage Atanarjuat (2001) de Zacharias Kunuk et dans les courts-métrages issus du Nunavut Animation Lab (2010). De même, nous verrons comment l'autochtonisation des médiums (cinéma, littérature) et les stratégies qui s'y rattachent (par exemple l'absence de sous-titres pour certains dialogues) encouragent l'auditoire à adopter de nouvelles positions spectatoriales.

\begin{abstract}
Indigenous Peoples of Canada have been for many decades the spectators of their own representation, their histories and cultures having been written, told and put into images by external mediators who were seldom able to accurately translate the subtleties of a culture based on oral tradition. However, in the last thirty years, Indigenous communities have developed numerous strategies which have helped them in their quest to decolonize their culture, using, among others, the languages of the colonizers to explore the possible renegotiations of languages, by integrating words and even complete sentences of their own language to their own works, written in either French or English (Henzi 2010). The Indigenizing of Canada's official languages and the greater visibility of Indigenous languages has become a way for indigenous writers, artists and filmmakers to re-appropriate their oral culture through remediation. In this vein, this article proposes to explore what we call the vocal-body; in Inuit poetry, in Zacharias Kunuk's feature-length film Atanarjuat (2001) and in the short-films hailing from the Nunavut Animation Lab workshop (2010). Moreover, we wish to show how the Indigenizing of the mediums (cinema, literature) and the strategies that are used by the artists (for example the absence of subtitles for certain dialogues) encourage the audience to adopt new viewing practices.
\end{abstract}

\section{Keywords}

Film, representation, remediation, Inuit studies, language 